\title{
Intangible heritage, and future past of rural Vietnam: a hero's journey and creative place-making of Yen Tu's tourism
}

\section{Sandra Goh and lan Seymour Yeoman}

Sandra Goh is based at the Department of Tourism and Events, Faculty of Culture and Society, Auckland University of Technology, Auckland, New Zealand. Ian Seymour Yeoman is based at the Department of Management, Victoria University of Wellington, Wellington, New Zealand and European Tourism Futures Institute, Stenden University of Applied Sciences, Leeuwarden, The Netherlands.

Received 28 December 2019 Revised 7 February 2020 19 February 2020

Accepted 23 February 2020

(c) Sandra Goh and lan Seymour Yeoman.

Published in Journal of Tourism Futures. Published by Emerald Publishing Limited. This article is published under the Creative Commons Attribution (CC BY 4.0) licence. Anyone may reproduce, distribute, translate and create derivative works of this article (for both commercial and non-commercial purposes), subject to full attribution to the original publication and authors. The full terms of this licence may be seen at: http:// creativecommons.org/licences/ by/4.0/legalcode

The authors wish to thank the Chairman of Legacy Yen Tu, Mr Tuan, for his valuable time and support in our research. Special appreciation to Huong, for her excellent translation during the interview, Mr Long, Ms Ha and Ms Quyen for sharing the hidden gem of Quang Ninh province, and Quang Ninh Department of Tourism for the statistics adapted in Table I.

\begin{abstract}
Purpose - This paper aims to look at the future development of new tourism attractions through the visionary project of a leading Vietnamese developer in a remote area of Northern Vietnam in the Quang Ninh province.

Design/methodology/approach - Drawing from the theoretical perspective of place-making and the hero's journey, this paper draws insights from a case study, an interview with two key informants in the private sector and literature review, to generate the drivers that will shape the future of tourism development in Yen Tu.

Findings - This paper identifies the visionary hero (leader), intangible heritage and creative placemaking as the key drivers that will reconstruct and repackage the past for developing tourism destinations.

Originality/value - This paper extends the existing knowledge in the literature about the natural heritage and sacred mountains of Yen Tu, and included creative place-making to gain insights into the future of tourism development in rural areas.
\end{abstract}

Keywords Yen Tu, Intangible heritage, Creative placemaking, Hero's journey, Rural, Cultural, Tourism futures

Paper type Trends paper

\section{Introduction}

To many tourists, the UNESCO-listed Ha Long Bay may be inextricably linked to Vietnam. However, the name Yen Tu may not bear any form of impression to the tourists, except for the domestic spiritual tourism market. A search on Google Scholar also confirms a lack of research in the location, what could be a role model for a bottom-up approach to creative place-making in a natural environment. The perspective of this research is underpinned by the theoretical knowledge of creative place-making and proposes that histories and stories of different stakeholders, provides answer to the future prosperity of a place, and is worthy of the attention of destination marketer, placemakers and further research by tourism scholars and futurists.

Although city planning and futures studies both concern about the future (Ratcliffe and Krawczyk, 2011), this trend paper reveals a significant lack of research in existing futures literatures on creative place-making. Place-making is a collective act, and it reinforces relations between community members, established the foundations of a culture and enhances the sense of place of the communities and their people. Creative place-making animates both public and private spaces, rejuvenates structures and streetscapes and brings diverse community together to celebrate, inspire and be inspired (Markusen and Gadwa, 2010). According to Lew (2017), the roles of place-makers are often taken for granted by specifically ancient and traditional cultures around the world, where the role of 
placemaking rest upon the public sector (Yea, 2002). Even a 25 years of literature review of journal articles published between 1991 and 2016, on the trends and gaps of place-making in the context of urban development and tourism by Dupre (2019), did not find the word "futures" appearing in the literature.

Many city leaders have depended on Florida's (2003) work on the rise of the creative class, as the agent of change. According to Florida, the creative class creates a new economy for a place. Florida $(2003,2012)$ refers the creative class to scientist, engineer, architect, designer, writer, artist, musician and the gay community. His study focuses on diversity and creative talents as basic drivers of innovation and regional and national growth of a place. This trend paper demonstrates a scenario contrary to Florida's, where members of the creative class are not readily available in a rural area - one local visionary leader from the local community rose to change the story of a rural economy with a masterpiece development that resembles what was unknown to him as the work of a creative placemaker. This bottom-up approach to place-making is evident in this trend paper.

A five-star luxury hotel, Legacy Yen Tu, was recently launched in Yen Tu, Quang Ninh province. The accommodation is another of MGallery's collection. The project represents a leader's dream to sustain the environment, culture and traditions of a sacred site. Located at the foot of the mountain, Yen Tu Legacy boasts of Vietnam's past from the thirteenth century. Beyond the walls of the luxury resort stood a new village, constructed and complete with Lang Nuong, a hostel accommodation. Inspired by the Golden Stupa (a commemorative monument), which stood since the thirteenth century, Legacy Yen Tu had repurposed a once-abandoned village, into an ancient palace of the Tran dynasty with state-of-the-art architecture. The property is completed with zen pool, meditation room and no lack of reflective spots, wellness workshops and also a museum in the making.

Leaders are key informants for futurists (Hambrick, 2007). This trend paper will provide an overview of Yen Tu and the leadership of a creative place-maker. Two drivers were identified in the paper:

1. the visionary leader as the hero and brining intangible heritage to life; and

2. creative place-making.

Quotes by the informants in this paper have been translated into English, as the interview was conducted in the presence of an interpreter.

A journal was kept by the researcher with verbatim notes. The interview lasted for an hour and a half in Legacy Yen Tu (2019) in November 2019.

\section{About Yen Tu and the new village}

Yen Tu is located between Hanoi and Halong Bay in Quang Ninh Province, a northeastern coastal province. It emerged as a new destination in late 2018, when connectivity to the province from Hanoi was completed. This included the new Hanoi-Hai Phong expressway, as well as the launch of the Hon Gai International port and Van Don International Airport (Carruthers, 2019). Table I shows Quang Ninh tourism statistics has been growing steadily, with international arrivals growing at a faster rate compared to domestic arrivals, except in 2018 and 2019, the period when the new transport infrastructures were in place. However, these are not statistics specifically on Yen Tu.

In 2015, it was gazetted that the Yen Tu relic site was included in the UN Educational, Scientific and Cultural Organisation's (UNESCO) list of nominated heritages (UNESCO, 2019; Vietnam Net, 2015; Vietnam News Agency, 2015). Located on the 1,068 m Yen Tu Mountain, in Quang Ninh Province, Vietnam, the 20,000-ha sacred site is considered the mecca of Vietnamese Buddhism. In the thirteenth century, King-Monk Tran Nhan Tong (1258-1308) founded the first Vietnamese School of Buddhism called "Thien Tong" or Truc 
Table I Quang Ninh Tourism statistics 2015-2019

\begin{tabular}{|c|c|c|c|c|c|c|c|}
\hline Description & Unit & 2015 & 2016 & 2017 & 2018 & 2019 & Cumulative \\
\hline A- Total number & Arrival & $7,767,500$ & $\begin{array}{c}8,350,000 \\
7 \%\end{array}$ & $\begin{array}{c}9,872,985 \\
18 \%\end{array}$ & $\begin{array}{c}12,245,741 \\
24 \%\end{array}$ & $\begin{array}{c}14,005,090 \\
14 \%\end{array}$ & $52,241,316$ \\
\hline Domestic visitor arrival & & $5,008,000$ & $\begin{array}{c}4,850,000 \\
-3 \%\end{array}$ & $\begin{array}{c}5,588,872 \\
15 \%\end{array}$ & $\begin{array}{c}7,016,741 \\
26 \%\end{array}$ & $\begin{array}{c}8,255,975 \\
18 \%\end{array}$ & $30,719,588$ \\
\hline International visitor arrival & & $2,759,500$ & $\begin{array}{c}3,500,000 \\
27 \%\end{array}$ & $\begin{array}{c}4,284,113 \\
22 \%\end{array}$ & $\begin{array}{c}5,229,000 \\
22 \%\end{array}$ & $\begin{array}{c}5,749,115 \\
10 \%\end{array}$ & $21,521,728$ \\
\hline B-Overnight Staying Number & Arrival & & & & & & \\
\hline 1-Arrivals & & $3,979,179$ & $\begin{array}{c}4,300,000 \\
8 \%\end{array}$ & $\begin{array}{c}4,633,600 \\
8 \%\end{array}$ & $\begin{array}{c}5,189,632 \\
12 \%\end{array}$ & $\begin{array}{c}5,612,508 \\
8 \%\end{array}$ & $23,714,919$ \\
\hline Domestic visitors & & $2,542,467$ & $\begin{array}{c}2,400,000 \\
-6 \%\end{array}$ & $\begin{array}{c}2,383,408 \\
-1 \%\end{array}$ & $\begin{array}{c}2,476,952 \\
4 \%\end{array}$ & $\begin{array}{c}2,669,727 \\
8 \%\end{array}$ & $12,472,554$ \\
\hline International visitor arrival & & $1,436,712$ & $\begin{array}{c}1,900,000 \\
32 \%\end{array}$ & $\begin{array}{c}2,250,192 \\
18 \%\end{array}$ & $\begin{array}{c}2,712,680 \\
21 \%\end{array}$ & $\begin{array}{c}2,942,781 \\
8 \%\end{array}$ & $11,242,365$ \\
\hline C-Average length of stay & & 1.76 & 1.86 & 2.16 & 2.60 & 2.74 & \\
\hline & $\begin{array}{l}\text { Million US } \\
\text { dollar }\end{array}$ & 492 & 584 & 788 & 1,021 & 1,272 & 4,157 \\
\hline
\end{tabular}

Lam Yen Tu Zen (Vietnam Tourism, 2015). Besides numerous temples, it also preserves many old religious and cultural documents such as precious prayer-books and monks' writings. The main commercial business then was managed by a cable car company. Before the cable car, the only mode of transport for the pilgrims is to visit the mountain on foot. The hike could take an average of four to six hours to the summit of the mountain. Apart from the places of worship on Yen Tu mountain, there is no other tourist attractions around the area. Vietnamese pilgrims would plan an early start from Uong Bi City, 17-km away, or camp on mats in local restaurant verandas before climbing the mountain. The mode of transport is also limited from the city of Ha Long to Yen Tu. The cable car operator is responsible for developing today's luxury resort and village stay experience at Yen Tu, known as Legacy Yen Tu.

The visionary plan came about after a trip by the Chairman of Legacy Yen Tu (the key informant), to the top of Yen Tu mountain. There he saw exactly where the spot for the property should be, to reinstate the story of King-Monk Tran Nhan Tong's legacy. It was said that the same journey had been taken by the King, before he decided to be a monk. It should be noted that the stories were collected from a conversation by a leading member of the intangible heritage research team with the developer. Without the stories, one would be convinced that the themed accommodation had been restored from an existing past structure. However, that was not the case. The architecture was a combination of a leader's dream, an architect's impression and a replica of the past. The construction and architectural design were meticulous, up to the point of using ancient techniques and proper curation of interior décor, to furnish the entire property. If the stories were untold, one would be convinced that the entire place was existing before and had been restored to its present state. It was a masterpiece that transport one back to the image of ancient Vietnam (Plate 1).

\section{The futurist, leader and planner}

As the upper echelons or the top management of the organisation (Hambrick, 2007), the leaders are regarded as the key informants, natural observers, privilege of their position within a society, who are capable of providing rich insights about the environment around them. They are prevy to the behaviour and cultural development of those around them. The following drivers illustrate the visionary leader as the futurist-leader-planner, who embodies and represents the culture of the environment and in constructing a new identity for the local 


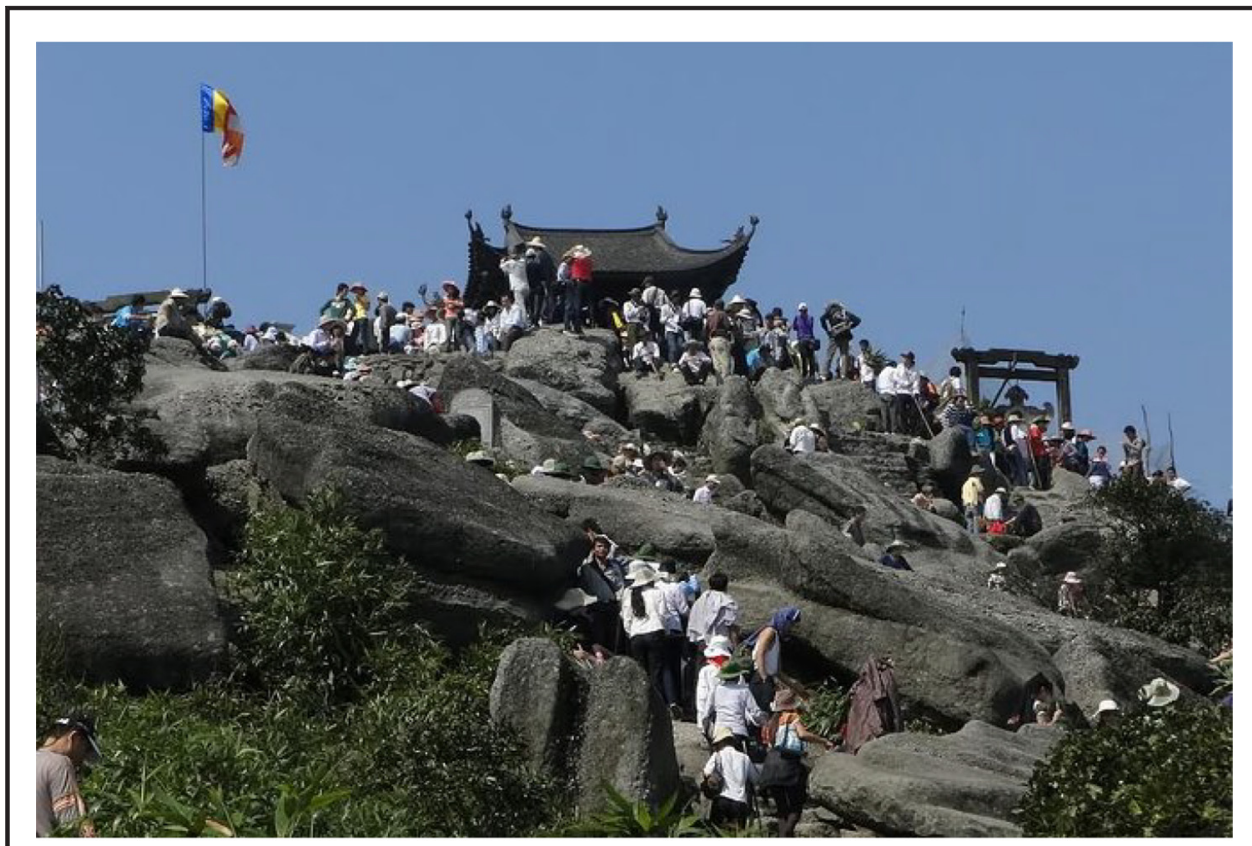

Source: Lonely Planet (2017)

people and the younger generations of Vietnamese who have forgotten about their heritage. The real value of futures approach in city planning is in the "imagineering" of novel way to address the development (Ratcliffe and Krawczyk, 2011). We saw the leader taking the futurist cum planner roles initiating a dream project with the constituent stakeholders of the territory, before the active participation of the city planners.

\section{Driver 1: the visionary leader as the hero and bringing intangible heritage to life}

"The universe is made of stories, not atoms." - Muriel Rukeyser.

How many times have we transformed after a hike or climbed a mountain to overcome some personal issues and decided on a drastic change and/or decision in our lives after our descend from that heights, that also bring about the greater good of the community around us? - There was a legendary story about a hero who took on that life-transforming journey once upon a time, overcoming obstacles and perils before he found wisdom and enlightenment. He became the new leader, sharing his new-found treasures with the community. Such stories follow a specific narrative pattern and was identified by Campbell (1949) as the hero's journey. A similar transformational experience was also observed in the narrative of the conversation I had earlier with the lead-researcher of the intangible heritage team, Long. The conversation was not recorded. Long introduced me on a journey of the late king who went up to Yen Ten Mountain and later decided his to devote his life to monkhood. During 20 years of his reign as king, the king had won two battles in the 1300s. $\mathrm{He}$ attained enlightenment after spending 10 years on the mountain. He founded the Vietnamese Zen school, Truc Lam (Różycka-Tran and Tran, 2014). He decided to be a monk, leaving his queen and concubines behind. In my conversation with the Chairman, another hero's journey was present that inspired his own legacy. The chairman had taken the same journey to the top of the mountain in search of an inspiration for the new development - the result, was the transformation of a sacred destination for pilgrims, to one 
that also provides themed accommodation to experience the Zen and ancient past of the destination. The Chairman said:

Vietnamese have little knowledge of the history of the dynasty under king Tran Nhan Tong [...] I see my role in awakening the society of Vietnam about our religion - when we discovered Yen

Tu, many of the pagodas were ruined.

The project was not met without resistance by various stakeholders in the community including the provincial government and the scrutiny of the media. However, the support from the religious leaders and the publicity as a result of the dialogue of the proposed development helped to escalate the plan.

Pilgrims to Yen Tu can now enjoy a longer stay in Yen Tu before and after their spiritual rites to the mountain. Legacy Yen Tu is also now home to the International Yoga Day in Vietnam. It was also revealed in the conversation with Long, that the late king's concubines had thrown themselves into a river from a bridge at the foot of Yen Tu's mountain, to prove their love to the king, when he decided to devote his life to monkhood and to remain on the mountain. Although the bridge is no long there, a new bridge was constructed in the village, as a remembrance of Yen Tu's past. Notwithstanding a tragic love story, the story added suspense and a mysterious past that one would not resist to experience at the top of the mountain (Plates 2 and 3).

Although the intangible stories from Yen Tu's past has commodified heritage, it has also helped resurrect and animate the past for the younger generation in Vietnam. This has also resulted in repeat visits among the youths and their families to Yen Tu.

\section{Driver 2: creative place-making}

In the anatomy of a creative city, the stakeholders are represented by three layers: upper ground, middleground and underground (Cohendet et al., 2010). The upperground is represented by formal units of the creative process. They are characterised by the innovative institutions, universities, cultural and research centres. The middle ground represents the broker who brings the underground players and the upperground together. The underground represents the creative, cultural and the artistic members in the community. In the context of this scenario, we refer to our key informant in this study, as the broker, or representative of the middleground, who is

\section{Plate 2 A postcard of Legacy Yen Tu}

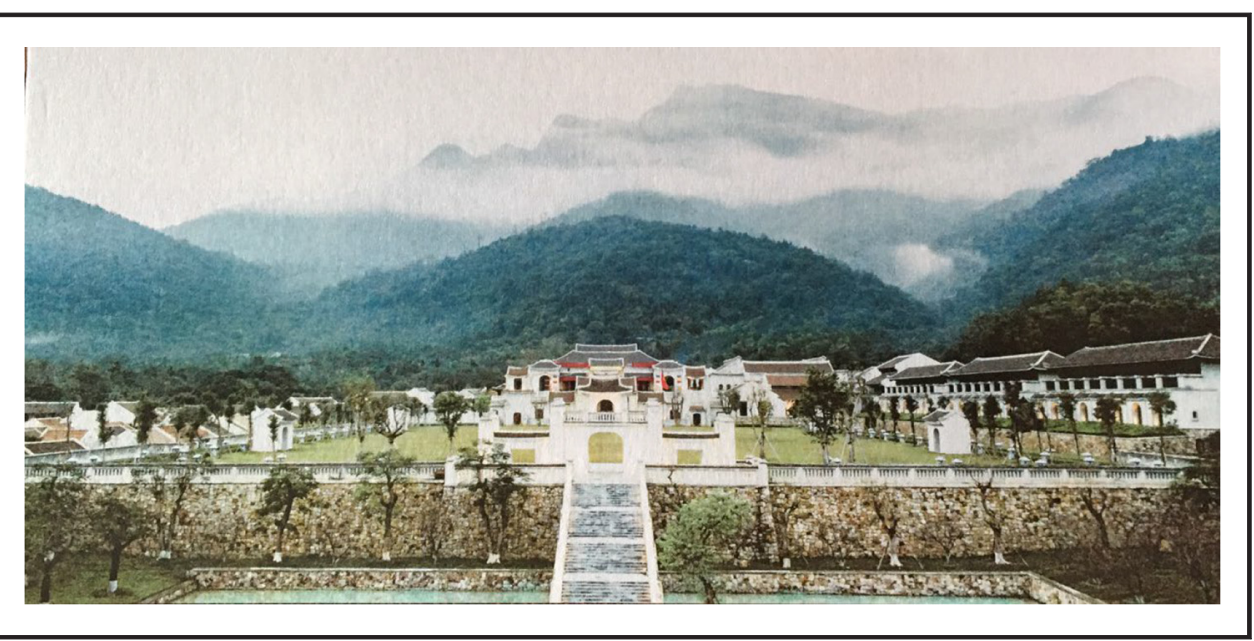


Plate 3 In the background, an artist's impression portrait of the king's favourite queen and the tiger, inspired by the story of her courage when she protected her king from the beasts

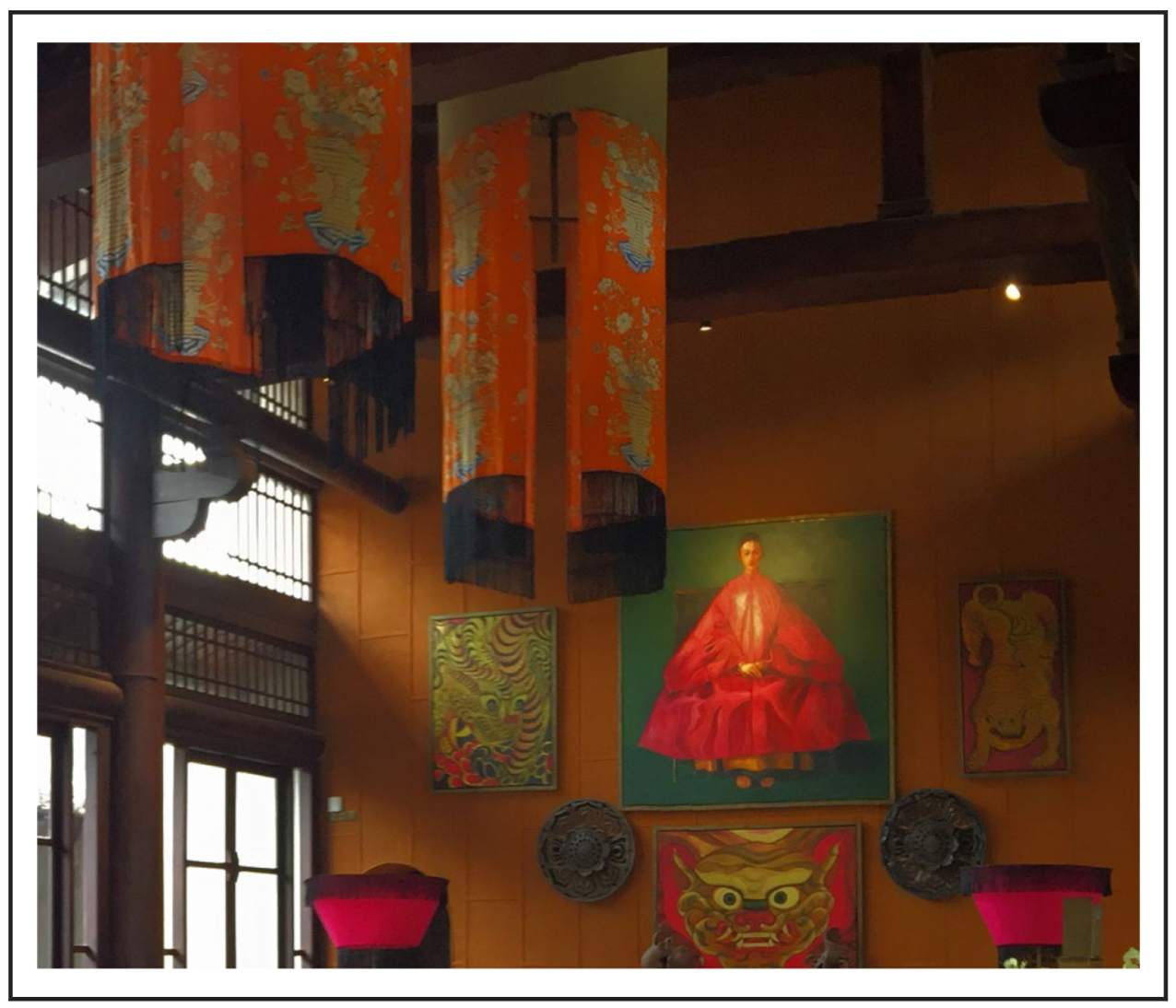

capable of pulling both the upperground and underground together for creative place-making.

When asked, the term place making, placemaking or place-making, may not be terms that were familiar to the Chairman, although he was already observed to be involved in the whole process of re-making Yen Tu. Lew (2017) has meaningfully unpacked the terms with three different approaches. Place-making refers to the more organic, bottom-up approach, where places are shaped by regular social practices (Lems, 2016). Ethinic cuisines and food are among the essential organic place-making commodities that appeal to tourists (Everett, 2012), although religious art and heritage, like in the case of Yen Tu, do more to reconstruct the past of the location. Place-making is more unstructured and spontaneous, as compared to the top-down approach of placemaking (Smith, 2002), where the public sector has more control and master planned, and consisting of modern, cosmopolitan and professional design and marketing influences. Placemaking is a blended approach of the two that incorporates both the elements of the organic and the planned approach - also known as the ideal model of partnership adopted by the best tourism places (Bosman and Dredge, 2011). Yen Tu's case is one that began with place-making. This was observed in the narrative of the Chairman: "In 1981, the monk wants Yen Tu to develop again [... .] it took us 20 years to resurrect Yen Tu". This driver calls attention to the role community leaders play in initiating the future development of new tourism attractions and/or destination, that this trend paper suggests.

Previous research on Yen Tu has been confined to the research on the sacred mountain (Lauser, 2015) and sustaining the life of the biodiversities on Yen Tu's mountain (Hecht 
et al., 2013; Le and Shibata, 2019; Tran et al., 2008). Although Le and Shibata drew the attention on the local culture and community of Yen Tu, it has not gone beyond the mountain terrain. The recent development of Legacy Yen Tu is a good example of not only placemaking but also creative place-making.

The term creative placemaking was mooted by Markusen and Gadwa (2010, p. 3), in a report for National Endowment for the Arts in America:

In creative placemaking, partners from public, private, non-profit, and community sectors strategically shape the physical and social character of a neighborhood, town, city, or region around arts and cultural activities. Creative placemaking animates public and private spaces, rejuvenates structures and streetscapes, improves local business viability and public safety, and brings diverse people together to celebrate, inspire, and be inspired (p.3).

Creative placemaking helps in shaping community identity, identify and acknowledge local assets as their marketing strengths. It fuses a collection of ideas and imaginations besides repurposing spaces (Kelkar and Spinelli, 2016). Legacy Yen Tu provides just that. It introduces a legacy for Yen Tu's forgotten spiritual past with a heritage theme resort. The opulent five-star resort may sound dear to one, but the prices are humble and welcomes both domestic and international tourists. The resort's interior décor is purposively curated by the developer's own research team on intangible heritage. The lobby greets one with a touch of a museum's grandeur. It brings impression of bright and bold colours from the past to the present. Beyond serving the religious pilgrims that frequents the mountain, the resort is focusing on the wellness market. The resort also boasts of a museum of the late king. An intimidating spacious, and long event hall also reminds one of the ancient royal court where the king governs. Beyond the wall of Legacy Yen Tu is the remaking of the village concept of Vietnam. Visitors relive the past with staged cultural street performances, and ethnic minorities paddling their food, medicinal herbs and handicrafts. Local artisans were invited to demonstrate and sell their traditional goods and services such as silk weaving, Vietnamese hats and wooden flutes (to name a few), while traditional arts and culture are displayed in the village square, through their daily performances (Plate 4).

A key function of destination planning is to make decisions in the present that will create economically, culturally and environmentally sustainable cities (Ratcliffe and Krawczyk, 2011). According to Mr Tuan, when Vietnam was economically poorer 20 years ago, many businesses did not comprehend the significance of sustainable business. However, he has already recognised it then. And by using the support of the other stakeholders' leaders in his vision to resurrect the heritage of Yen Tu, Mr Tuan's inclusive development plan that involves the restoration of heritage and culture was a winning formula.

\section{Conclusion}

This paper has added to our understanding about the value of intangible heritage, sustainable cultural development and the value of storytelling in the development of new tourism attraction in a rural area. The hero's journey which was previously introduced in transformational tourism research was applied to the vision of a futurist-leader for the first time and is worthy of further examination in evaluating foresights following its process (pre, during and the post journey of the hero). It also contributed to our understanding of key informant and the transformational and sustainable change they are capable to imbue to a place. In Mr Tuan's case, the consent and support of the religious leaders had paved the way for the restoration of a sacred site on a mountain and the reconstruction of its past on the ground. By focusing on the past developmental trend of a rural locale in Vietnam, two drivers were identified for further research into the development of new tourism attractions and creative place-making in a natural environment. This trend paper highlights the critical 


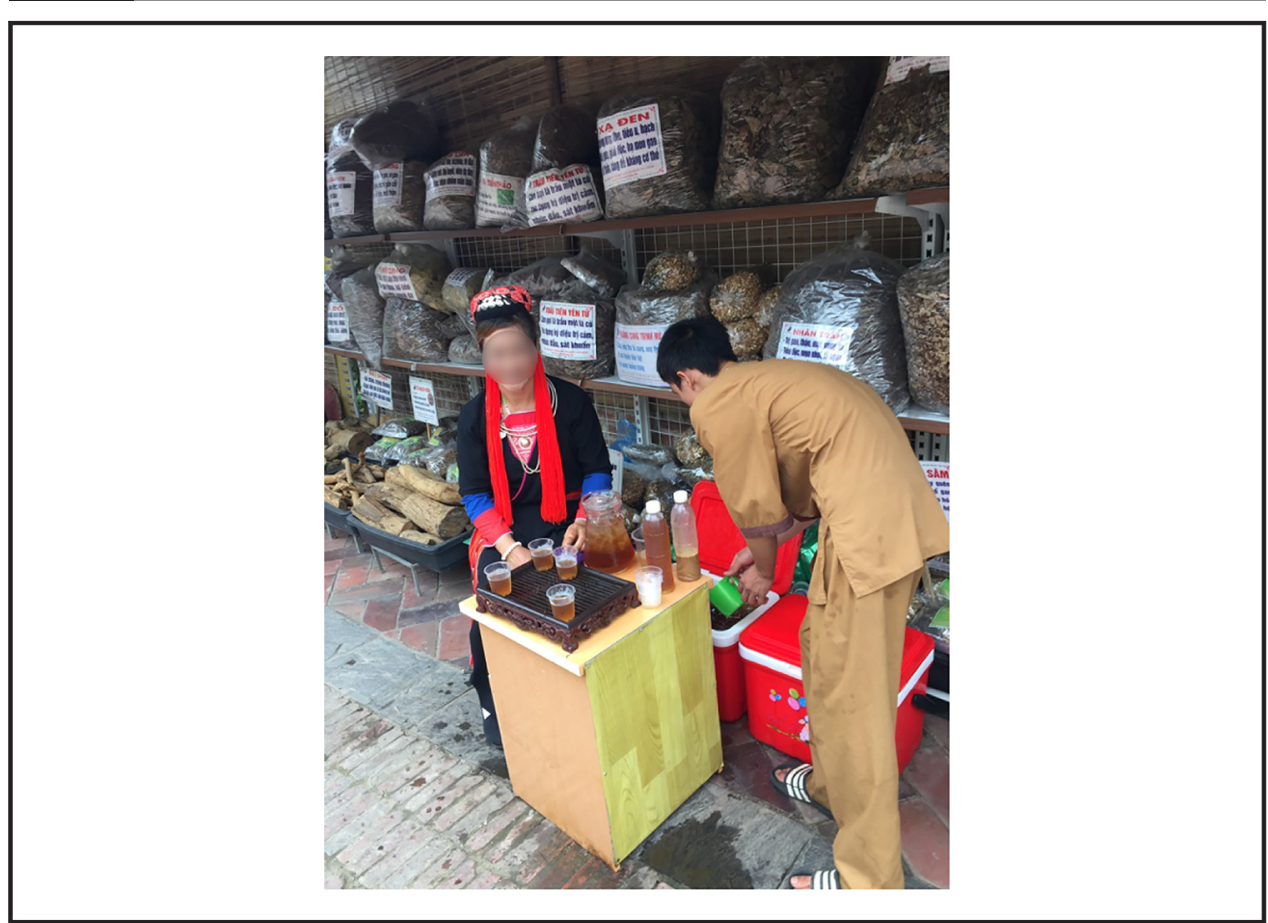

importance of a local community leader with not only foresight and financial capability but also commitment to the community, heritage and cultural past of the place to create sustainable stories, employment and legacies for the local community. A place may not possess any tangible heritage, but the legacy of intangible heritage can be materialised with the partnership of creative place-makers. As the Chairman said: "[...] the company is not just about making money, [...] or economic development. The foundation of the business is the culture of the place[...]".

\section{Limitation and recommendation}

As this is a trend paper, and Yen Tu is still a relatively new destination to international tourists, the data specific to the area are not immediately available to us. Presently, only statistics showing local and international visitors to Quang Ninh province are available from Quang Ninh Department of Tourism. Without statistics on Yen Tu and/or Uong Bi City, we are unable to make any meaningful comparison. Future research could include analysis of overnight visitor stay at Yen Tu. It will be worthy to conduct a longitudinal study to analyse her growth on a year-on-year basis and to examine if the new village and accommodations in Yen Tu would result in the increase number of visitor arrivals and length of stay.

This trend paper has helped expand the concept of creative place-making in a natural environment. Future research could develop on this paper to observe the leadership role in developing the identity of the community, in envisioning new, unique and yet authentic tourism attractions. Further analysis on the application of creative placemaking concept would be necessary to verify the drivers proposed in this trend paper - perhaps, timely for tourism researchers, futurists and leaders, to take stock of desired futures ever studied and evaluate the transformation of the here-now (Burke, 2009)? 


\section{References}

Bosman, C. and Dredge, D. (2011), "Histories of placemaking in the Gold Coast City: the neoliberal norm, the state story and the community narrative", Griffith University-Urban Research Program, Research Paper, Vol. 33.

Burke, R. (2009), "From strategic foresight to conversations about alternative and desired futures using scenarios to transform the present", Journal of Futures Studies, Vol. 13 No. 3, pp. 99-104.

Carruthers, M. (2019), "Quang Ninh tourism to grow beyond Halong Bay", available at: www.ttgasia.com/ 2019/01/16/quang-ninh-tourism-to-grow-beyond-halong-bay/ (accessed: 2 February 2020).

Cohendet, P., Grandadam, D. and Simon, L. (2010), "The anatomy of the creative city", Industry \& Innovation, Vol. 17 No. 1, pp. 91-111.

Dupre, K. (2019), "Trends and gaps in place-making in the context of urban development and tourism", Journal of Place Management and Development, Vol. 12 No. 1.

Everett, S. (2012), "Production places or consumption spaces? The place-making agency of food tourism in Ireland and Scotland", Tourism Geographies, Vol. 14 No. 4, pp. 535-554.

FL, R.L. (2003), The Rise of the Creative Class: And How It's Transforming Work, Leisure, Community and Everyday Life, Basic Books, New York, NY.

FL, R.L. (2012), The Rise of the Creative Class, Revisited, Basic Books, New York, NY.

Hambrick, D.C. (2007), "Upper echelons theory: an update", Academy of Management Review, Vol. 32 No. 2, pp. 334-343.

Hecht, V.L., Pham, C.T., Nguyen, T.T., Nguyen, T.Q., Bonkowski, M. and Ziegler, T. (2013), "First report on the herpetofauna of Tay Yen Tu nature reserve, northeastern Vietnam", Biodiversity Journal, Vol. 4 No. 4, pp. 507-552.

Kelkar, N.P. and Spinelli, G. (2016), "Building social capital through creative placemaking", Strategic Design Research Journal, Vol. 9 No. 2, pp. 54-66.

Lauser, A. (2015), "Traveling to Yên Tử (North Vietnam). Religious resurgence, cultural nationalism and touristic heritage in the shaping of a pilgrimage landscape", DORISEA Working Paper Series, No. 20.

Le, K.L. and Shibata, S. (2019), "May. Sacred Forest and tourism: focusing on sacred Yen Tu Mountain in Vietnam”, 日本森林学会大会発表データジース第 130 回日本森林学会大会,日本森林学会, p. 37.

Legacy Yen Tu (2019), "Hotel stories", available at: www.legacyyentu.com/hotel-stories/ (accessed 26 December 2019).

Lems, A. (2016), "Placing displacement: place-making in a world of movement", Ethnos, Vol. 81 No. 2, pp. 315-337.

Lew, A.A. (2017), "Tourism planning and place making: place-making or placemaking?", Tourism Geographies, Vol. 19 No. 3, pp. 448-466.

Lonely planet (2017), "Yen Tu Mountain day trip from Ha long", available at: www.lonelyplanet.com/vietnam/ activities/yen-tu-mountain-day-trip-from-halong/a/pa-act/v-6528P289/357846 (accessed 26 December 2019).

Markusen, A. and Gadwa, A. (2010), Creative Placemaking, National Endowment for the Arts, Washington, DC, available at: www.arts.gov/sites/default/files/CreativePlacemaking-Paper.pdf

Ratcliffe, J. and Krawczyk, E. (2011), "Imagineering city futures: the use of prospective through scenarios in urban planning", Futures, Vol. 43 No. 7, pp. 642-653.

Różycka-Tran, J. and Tran, Q.A. (2014), "Self-Regulation techniques in Vietnamese Zen Truc lam monastery”, Gdańskie Studia Azji Wschodniej, No. 6.

Smith, N. (2002), "New globalism, new urbanism: gentrification as global urban strategy", Antipode, Vol. 34 No. 3, pp. 427-450.

Tran, T.T., Orlov, N.L. and Nguyen, T.T. (2008), "A new species of Cascade frog of Odorrana Fei, Yi et Huang, 1990 genus (Amphibia: Anura: Ranidae) from Bac Giang province (Yen Tu Mountain range, northeast Vietnam)", Russian Journal of Herpetology, Vol. 15 No. 3, pp. 212-224.

UNESCO (2019), "The complex of Yen Tu monuments and landscape", available at: https://whc.unesco. org/en/tentativelists/5940/. (accessed 26 December 2019). 
Vietnam Net (2015), "Yen Tu listed in UNESCO heritage nominations", available at: https://english. vietnamnet.vn/fms/art-entertainment/120872/yen-tu-listed-in-unesco-heritage-nominations.html. (accessed 26 December 2019).

Vietnam News Agency (2015), "Yen Tu listed in UNESCO heritage nominations", available at: https://vietnam. vnanet.vn/english/yen-tu-listed-in-unesco-heritage-nominations/114319.html. (accessed 26 December 2019).

Vietnam Tourism (2015), "Yen Tu listed in UNESCO heritage nominations", available at http:// vietnamtourism.gov.vn/english/index.php/items/8190. (accessed 26 December 2019).

Vietnam Tourism (2015), "Yen Tu Spring festival opens in Quang Ninh province", available at: http:// vietnam-tourism.com/en/index. php/news/items/12026. (accessed 26 December 2019).

Yea, S. (2002), "On and off the ethnic tourism map in Southeast Asia: the case of Iban longhouse tourism, Sarawak, Malaysia”, Tourism Geographies, Vol. 4 No. 2, pp. 173-194.

\section{Further reading}

Markusen, A. and Nicodemus, A.G. (2014), "Creative placemaking: how to do it well", Community Development Investment Review, Vol. 2, pp. 35-42.

Rukeyser, M. (1968), The Speed of Darkness, Random House, New York, NY.

Sofield, T., Guia, J. and Specht, J. (2017), "Organic 'folkloric' community driven place-making and tourism", Tourism Management, Vol. 61, pp. 1-22.

\section{Corresponding author}

Sandra Goh can be contacted at: sandra.goh@aut.ac.nz

For instructions on how to order reprints of this article, please visit our website: www.emeraldgrouppublishing.com/licensing/reprints.htm

Or contact us for further details: permissions@emeraldinsight.com 